Article

\title{
Female Clergy as Agents of Religious Change?
}

\author{
Kati Niemelä \\ Church Research Institute, P.O. Box 239, 33101 Tampere, Finland; \\ E-Mail: kati.niemela@evl.fi; Tel.: +358-40-754 1551
}

Received: 27 April 2011; in revised form: 4 August 2011 / Accepted: 12 August 2011 /

Published: 17 August 2011

\begin{abstract}
This article focuses on female clergy as potential agents of change in the Church. I argue that the adoption of female clergy is one of the main factors that cause the Church to change its practices, policies and theological orientation. The first female ministers were ordained in the Evangelical Lutheran Church of Finland in 1988. This is fairly late compared to other Nordic countries. However, the number of female ministers and female students has been growing fast and nowadays about 70 percent of theology students are female.

The paper is based on quantitative surveys conducted among the members of the Clergy Union in 2002, 2006 and 2010 ( $\mathrm{N}=$ about 1,000 each) and among the applicants for university studies in theology in 2010. The research shows that clergywomen are changing the Church in a clearly more liberal direction. They do it in various areas of church life: they change the perception of faith and dogma, the policies of the Church as well as daily practices in parishes. Clergymen are notably more traditional in their orientation, even young clergymen. Therefore it is especially the female clergy who serve as agents of religious change in the Church.
\end{abstract}

Keywords: clergywomen; female clergy; clergy attitudes; gender; gender roles; liberal and conservative approach; homosexual couples in the Church

\section{Abbreviations}

ELCF: Evangelical Lutheran Church of Finland 


\section{Introduction}

\subsection{Women in Ministry}

This article is about female clergy as agents of change in the Church: How do the often undermined clergywomen transform and change the Church from within? This article will analyze the question from a sociological perspective and it is based on empirical material. The entrance of women into the ordained ministry has been regarded as one of the most significant transformations in 20th century Christianity [1] and has changed both the institutional lives of the churches as well as the lives of those women who have been ordained [2]. Research indicates that female clergy themselves are in a key position to change the Church and that their role differs a lot in different churches [3]. Women, especially those in elite positions, have the potential to influence social change that benefits women's interests $[4,5]$.

The first women were ordained to ministry as early as in the middle of the 19th century. The denominations which were acting as pioneers in ordaining women into the ministry already before the 20th century include many different denominations with a liberal orientation. The first ordinations of women took place in 1853 in the Congregationalist Church, in 1863 in the Universalists denomination, in 1865 in the Salvation Army and in 1866 in the Methodist Protestant Church. Subsequently, the ordination of women has become accepted in most Protestant churches.

In the Nordic countries, female ministry was first adopted in Denmark, where the first female ministers were ordained in 1948. Sweden followed in 1960, Norway in 1961 and Iceland 1974. In Finland, female ministry was adopted in 1986 and the first female ministers were ordained in 1988. This is fairly late compared to other Nordic countries [6]. The first female bishop was ordained in Finland in 2010, which is again later than, for example, in Sweden (1996) and Germany (1992).

The number of female clergy has increased markedly in many denominations. However, women do not have the same impact in practice than clergymen have in the policies and actions taken by churches. [4,5] Despite the increase in the number of female clergy, the number of women in leadership positions increases slowly - if at all [7]. According to the National Congregation Study, $7.9 \%$ of congregations in United States had a female leader (in 2006/2007) [7]. This is about equal to the percentage of female vicars (head pastors in congregation) in the Evangelical Lutheran Church of Finland. In 2009 the share of congregation with a female leader was 8.5\% [8].The male and female clergy are also very differently employed in general. The Clergy Union member survey 2010 in Finland reveals that, among the clergymen, the most common position was vicar (the head pastor), with $29 \%$ employed as such. The second most common position was curate ( $2^{\text {nd }}$ pastor), with $26 \%$ employed as such. Among the clergywomen, the most common position was parish clergy (lower pastor) (41\%). Only $5 \%$ of the women worked as vicars. [9]

In general, clergywomen are becoming a more and more accepted presence in churches. However, despite formal acceptance, clergy women have faced subordination and discrimination in many Protestant denominations [10]. There is a lot of research on clergywomen and their experiences and most of all on the difficulties they encounter in their career. Research with different methods shows that there is a universal agreement by clergywomen that "glass ceilings" do indeed exist: women face passive discrimination in their career and have difficulties in advancing therein [10-14]. 
It is obvious that the career opportunities for clergywomen are not equal to those of male clergy. Women have difficulties in finding a job, entering leadership positions, and receive a lower pay for the same type of jobs. Male clergy are more likely to occupy managerial-type positions while clergywomen are more likely to occupy staff-type occupations - and this is not only of their own will. [4,7,10-16]. Women are also more likely than men to leave parish ministry [13,17].

Previous research also shows that women who succeed "too well" are often undermined by men. This may entail withholding information, sending double messages or in other methods, putting women into positions where they are likely to fail [5]. Within these difficulties, the spiritual or divine dimension of their profession is found to be extremely important for clergywomen. They have sought ordination-just like clergymen - because they have sense of calling and a conviction that God has a plan for their lives. This feeling sustains them when they face difficulties and discrimination [12]. Also, previous research on clergy in Finland indicates that both male and female clergy highlight the calling from God as the primary source of motivation. However this kind of orientation has declined among the younger clergy [18-21]. Research also indicates that both male and female clergy are in general very committed to working for the church and also committed to the church dogma. However, there are some differences between the two sexes: clergymen are more likely to believe in the existence of Hell and Satan and in Jesus' return, while females are more likely to believe in angels and miracles told in the Bible [22]. Narrative analysis of the faith among church workers revealed that there were also some differences between male and female workers in the way their faith was constructed, but it seemed that that age and educational level were stronger predictors than gender. It was characteristic for young and less educated workers to rely strongly on external authorities and avoid personal critical thinking [23]. Research shows that parishes where women typically have key positions are liberal in their basic orientation [7]. The liberal religious groups and individuals so disposed are more prepared than conservatives to adopt varying positions in religious issues. Those with liberal attitudes tend to be ecumenical and tolerant. It is typical for the liberals to stress performance, where an attempt is made first and foremost to apply religion to various social problems and the spiritual task of religion (function), pure religious communication, religious dedication and the quest for salvation are less emphasized. Attention may be paid to matters pertaining to poverty, environmental issues, human dignity and the identity of the individual [24,25]. The conservative groups are notably less likely to have female clergy in key positions [7]. Religious groups as well as individuals with this orientation tend to stress purely spiritual tasks, the basic function of religion. They take the view that the religious message of the Bible should be taken seriously and that as such it has something to say at this time. They are seriously committed to views they consider to be pure doctrine and take a traditional attitude to morality [24,25].

\subsection{Gender Roles}

Results from previous studies show that certain gender roles seem to be deeply rooted in the construction of the roles of female and male clergy. This not a unique phenomenon only visible in church settings, but characterizes work life and culture in general. Gender roles refer to the set of social and behavioral norms that are considered to be socially appropriate for individuals of specific 
sex in the context of a specific culture. There are differences of opinion if these observed gender differences are due to cultural or social factors or due to biological and physiological differences [26].

The social role theory of gender posits that it is the social structure that is the underlying force for the differences between men and women. The distal cause for the gender roles and hence division of labor is considered to be the physical specialization of the sexes - as men being physically stronger and bigger in body size provided them advantage in some activities etc. [27]. The traditional division of labor creates gender roles - or stereotypes, which in turn lead to gendered social behavior.

Socially constructed gender roles are characterized as a male-advantaged gender hierarchy [28]. Men are typically involved in activities that have more access to or control of resources and decisionmaking power rendering them higher status and authority. This labor division does not only exist in the paid labor market, but also in society in general, and the characteristics of the activities performed by women and men also become people's perceptions and beliefs of the attributes of women and men themselves [29].

Gender roles and stereotypes lead to sex-typed-social behavior. Roles and stereotypes are both socially shared descriptive norms and prescriptive norms [27]. People expect men and women who occupy certain positions to behave according to these attributes [29]. Viewed from this perspective, the differences that are found between clergywomen and men in work are related to the deeply rooted social structure in churches. This means that a clergywoman is likely to behave as she feels she ought to behave as a clergywoman and clergyman as he feels he should behave in this particular position.

\section{Research Questions, Context of Study and Data}

\subsection{Research Questions}

This article focuses on female clergy as potential change-makers in the Church. I argue that the adoption of female clergy is one of the main factors that cause the Church to change its practices, policies and theological orientation: female clergy are important agents of change in the Church. I will analyze the question from the following perspectives in the Evangelical Lutheran Church of Finland:

(1).How do female clergy change the theological orientation and the perception and content of faith in the Church? This is analyzed by comparing theological orientation and religiousness among male and female clergy.

(2).How do female clergy change the official policies of the Church? The case analyzed is the question of same-sex relationships and how the Church should act in it.

(3).How do female clergy change the daily practices and the vision of clergy work? This is analyzed by comparing male and female clergy orientations towards work and analyzing what they regard as key functions in the church work.

\subsection{Context of Study}

The Evangelical Lutheran Church of Finland (ELCF) is the majority church in Finland with $78 \%$ of Finns being members (in 2010) and with 2,300 parish ministers. In 2010, 40\% of parish ministers in the ELCF were female, but this share is expected to increase rapidly. During the 21 st century more than half of those ordained have been women and about $70 \%$ of those studying theology are female. 
The ELCF is a typical protestant mainline church which typically takes a middle position in most controversial issues. The Bible is typically seen as a book that is inspired by God, but should not be taken literally [22]. The Church does not control its members strictly and, for example, divorce and remarriage are accepted.

The late adoption of female ministry and bishops partly indicates that the Evangelical Lutheran Church of Finland (ELCF) seems to have remained more conservative than its Nordic sister-churches. The same tendency to change more slowly is also apparent in the actions taken regarding homosexual couples' rights in the Church. In November 2010, the General Synod of the Church issued a statement saying that the clergy can perform a prayer with same-sex couples entering a legal partnership. However, this prayer does not mean the Church's blessing on same-sex relationships or equivalence with marriage. In Sweden, homosexual couples were granted the right to a church wedding in 2009. In 2005, blessings had already been granted to same-sex couples. The Church of Denmark and the Church of Iceland also allow blessings of same-sex couples.

\subsection{Data}

The article is based on surveys conducted among the members of the Clergy Union in Finland. About $92 \%$ of all clergy belong to the Clergy Union. The survey was conducted in 2010, 2006 and 2002, at the same time as the elections of the Clergy Union representatives. The questionnaires were sent by mail to respondents' home addresses together with the Clergy Union representative election material. The number of respondents was 1,211 in 2002 (response rate 45\%), 1,076 in 2006 (41\%) and 878 in 2010 (39\%) [9,30,31]. In 2010, respondents were able to complete the questionnaire either via conventional surface mail or via Internet, and before that, only by conventional surface mail. In 2010, two out of three $(66 \%)$ replied by mail, one third by Internet. In the main data set, the analysis is based on the survey of 2010. The results from 2010 are compared with the results from previous surveys when feasible.

A fourth survey used in the analysis is a survey among those applying to study theology at university in 2010 in Finland. A total of 269 returned the questionnaire, of which 172 actually started their studies. In this article we shall only consider the responses of those who started their studies.

\section{Results}

\subsection{Female Clergy as Agents of Change in Theological and Belief Issues}

Research shows that female clergy are clearly more liberal in their theological orientation than male clergy. When the clergy were asked to evaluate whether they regarded themselves as theologically conservative or liberal, as many as $68 \%$ of female clergy regarded themselves as mostly or decidedly liberal, compared to $46 \%$ of male clergy (see Figure 1). Only $13 \%$ of women regarded themselves as mostly or decidedly conservative compared to $33 \%$ of male clergy. (The scale was from 1 to 5 , where 1 = theologically conservative, 2 = theologically mostly conservative, $3=$ in between, $4=$ theologically mostly liberal, $5=$ theologically liberal).

Liberal views were more common among the young female clergy, but among young male clergy the case was just the opposite. Conservative theological views were most common among young male 
clergy: of male clergy under 35 years old, half regarded themselves as mostly or decidedly theologically conservative compared with only one in ten of the young female clergy. Among the women, age and theological orientation correlate in a statistically significant level: the younger they are, the more liberal they are $(-0.12, \mathrm{p}=0.025)$. Among the men, the direction of the correlation is opposite $(0.06)$, but the level is not statistically significant $(\mathrm{p}=0.221)$. Regression analysis shows that theological orientation is clearly a gender issue (Beta $=0.244, \mathrm{t}=6.924$, sig. $<0.001$ ) and not an age issue $($ Beta $=0.16, t=0.449$, sig. $=0.654)$ and liberal views have increased with the increase of female clergy.

Figure 1. Theological orientation (self-report) among male and female clergy in different age-groups in Finland. Clergy Union member survey 2010, N = 878.

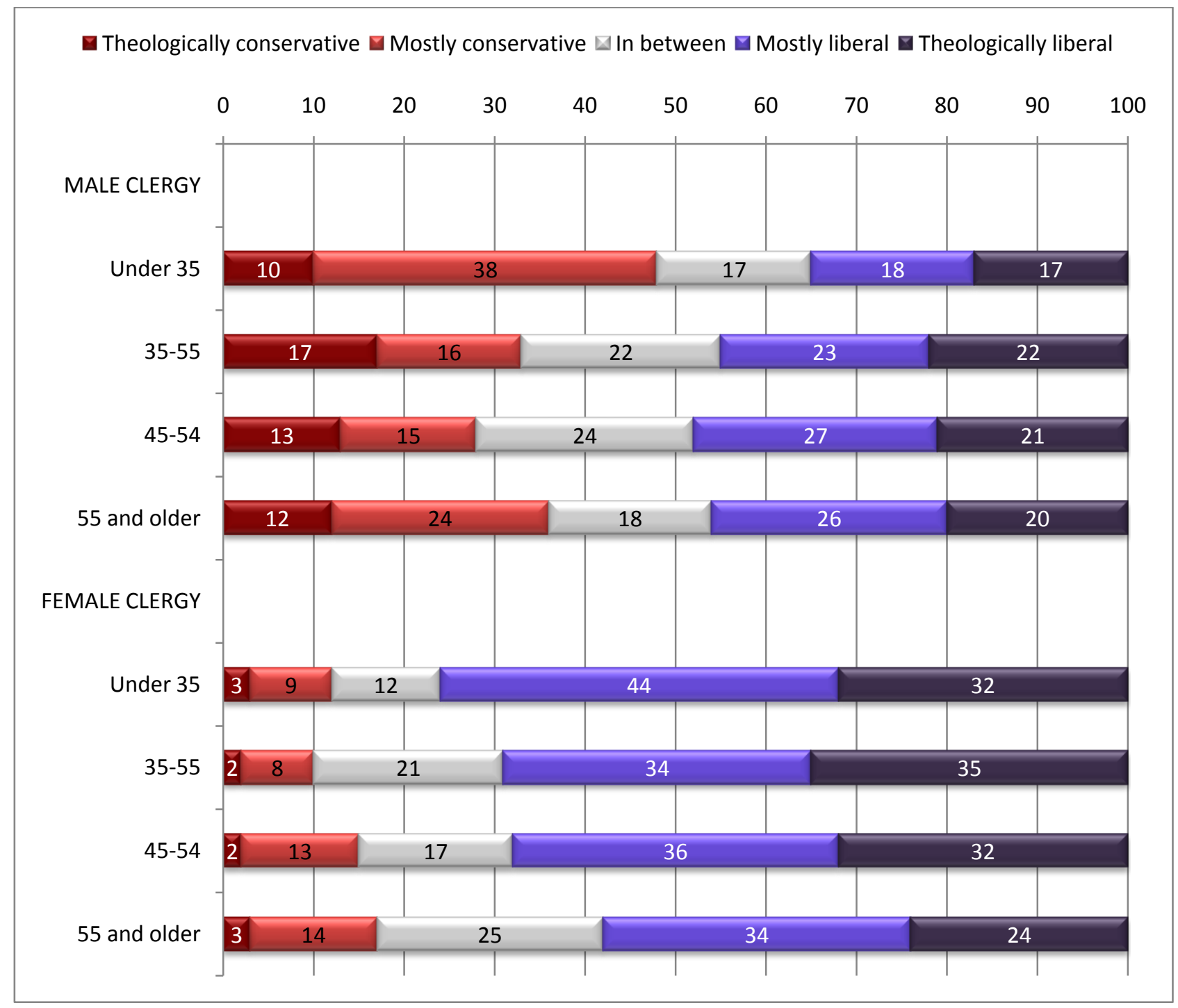

Among the mostly liberal young female clergy, Bible reading had notably declined (see Figure 2). Bible reading had also declined among the male clergy, but the change among female clergy is notably greater. Of the female clergy under 35 years old, only one in four $(28 \%)$ reported reading the Bible several times a week or daily for personal devotion while among the female clergy, over 55 almost three out of four (73\%) did so. Among the male clergy the same figures were $45 \%$ and $67 \%$. 
However, at the same time, there was no notable change in the number of clergy regarding faith as very important in their lives. It has nevertheless declined among the female clergy to some extent: $81 \%$ of clergy women over 55 years old regarded faith as very important, while the corresponding figure among the women under 35 was $73 \%$. Among male clergy there was no linear trend. Female clergy are more active in praying in all age groups than men, even though they are less active in reading the Bible. However, the number of clergy who pray daily has declined with age both among male and female clergy.

Figure 2. The share of male and female clergy in different age groups who read the Bible several times a week for personal devotion, regard faith as very important and prayed daily in $2010 . \mathrm{N}=878$.

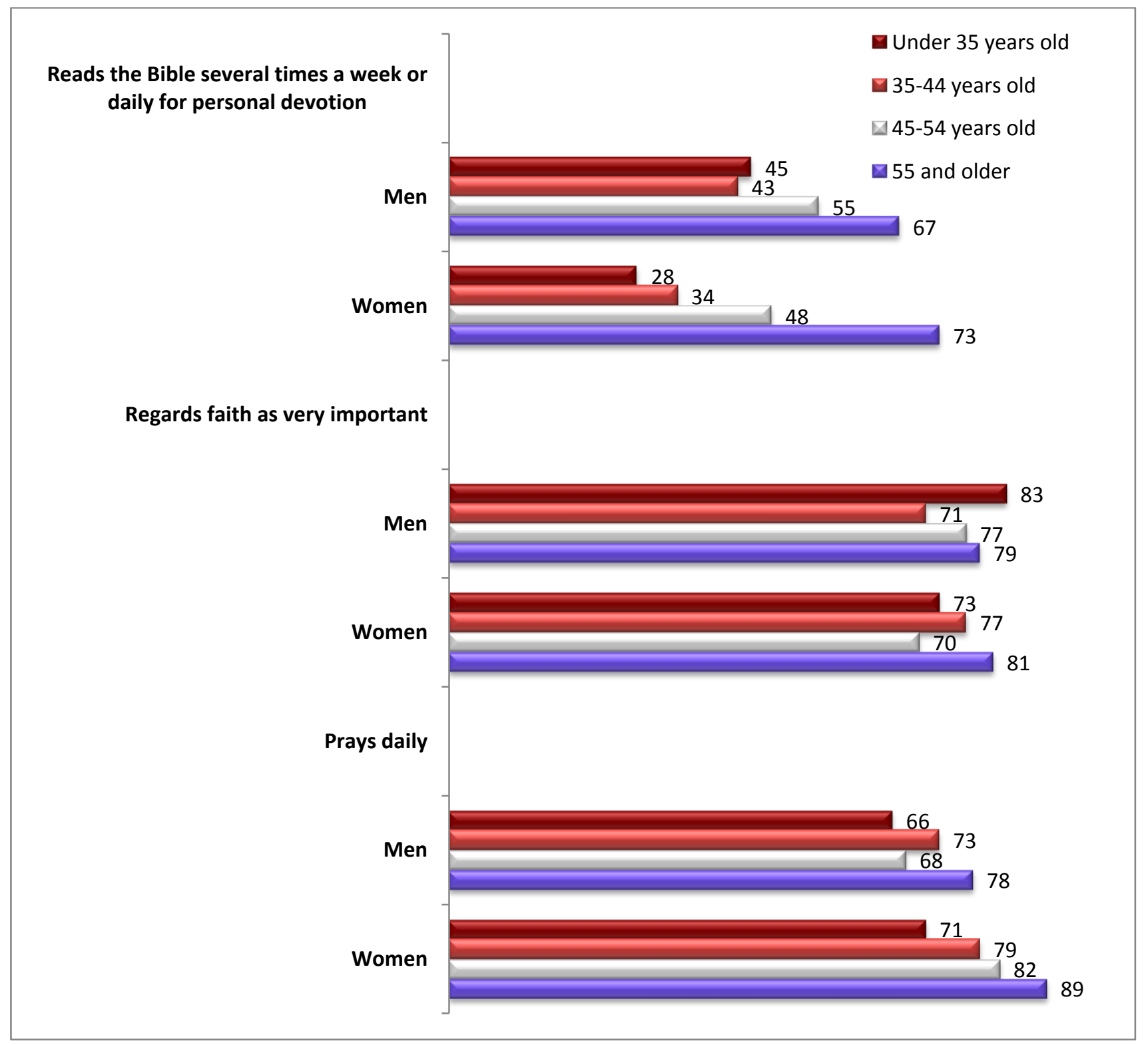

Differences in religiousness among male and female clergy do not follow the same pattern as differences between men and women in general. Various studies from both Finland and other countries 
indicate that women are clearly more religious in all age groups and notably more active, for example, in praying, reading the Bible or in how important they regard faith in life $[32,33]$.

Among female clergy, the content of faith seems to be more individualized than among clergymen: faith is deeply rooted in their personal lives, but they are less dependent on religious authorities like the Bible. This is supported by results from an earlier study indicating that female clergy in Finland are less likely than male clergy to believe totally in traditional Christian beliefs. For example, $76 \%$ of male clergy believed firmly that Hell exists, compared with only 58\% the female clergy [22].

\subsection{Female Clergy as Agents of Change in Church Policies}

I will next analyze the female clergy as agents of change in Church policies. The case I shall consider is the question whether the Church should grant registered same-sex couples a church blessing on their partnership. This has been a burning issue throughout the early 21 th century, but until now blessings have not been allowed in the Evangelical Lutheran Church of Finland. In 2010, the General Synod of the Church decided that the clergy can perform a prayer with these couples, but this is not synonymous with the Church's blessing. However, some clergy members have performed these blessings without the Church's permission. According to the Clergy Union Member Survey in 2006, of all clergy, nearly two percent said that they had performed such blessings. Almost all of them were female. Women were also notably more positive towards an option to do so even if they had not performed them. As many as 58\% of the female clergy reported that they could think of doing so. Among the male clergy, the share was $38 \%$.

The data shows that in general, the positive attitudes towards same-sex couples' opportunity for a church blessing on their partnership have become clearly more positive during the period for which we have collected data on it: in 2002 12\%, in $200623 \%$ and in $201031 \%$ of the clergy agreed totally that same-sex couples should be granted a Church blessing, while the number of those who totally disagreed had declined from $47 \%$ to $31 \%$ [20,21]. However, the data shows that it is mainly the female clergy who want the Church to change its policies in favor of same-sex couples (see Figure 3). Of the women, almost half agreed totally (42\%) and only 14\% disagreed totally in 2010 with a question "Should the registered same-sex couples be granted a church blessing?" At the same time the attitudes among male clergy are almost opposite. Of male clergy nearly half (45\%) disagreed totally and only one fifth $(22 \%)$ agreed totally. The share of male clergy totally opposed had declined only a little from 2002 to 2010 (from 57\% to 45\%). During the same period, the share of female clergy fully agreeing with the question had increased from $20 \%$ to $42 \%$, and the share of those women totally disagreeing had declined from $30 \%$ to $14 \%$. In 2002, the attitudes among clergywomen were already more positive than the attitudes of male clergy in 2010. The data from students starting a theology degree in 2010 shows that the tendency is likely to remain the same: male students are equally critical of same-sex couples' church blessing than male clergy. The attitudes among female students are also very much the same as among female clergy.

It is also worth noting that the female clergy are not more positive only because they are younger, but mainly because they are women. Regression analysis shows that gender is clearly a more meaningful factor explaining the attitudes (Beta 0.302, $\mathrm{t}=8.58 \mathrm{sig} .=0.000)$ than age (Beta $=0.074$, $\mathrm{t}=2.10$, sig. $=0.036$ ). 
Figure 3. Should same-sex registered couples be granted a church blessing? Responses among male and female clergy in $2002(\mathrm{~N}=1,211), 2006(\mathrm{~N}=1,076), 2010(\mathrm{~N}=878)$ and among starting students of theology in $2010(\mathrm{~N}=170)$.

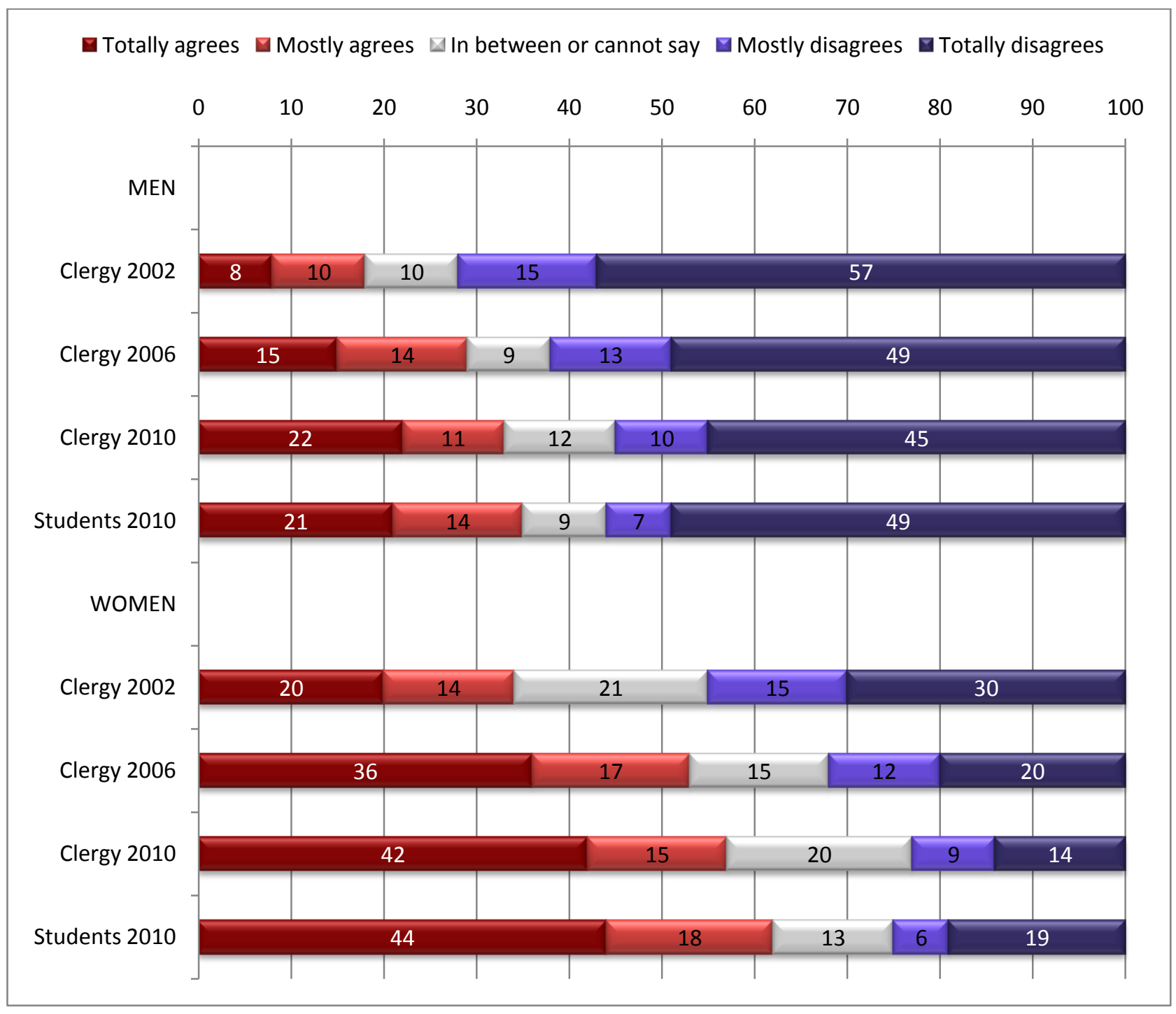

\subsection{Female Clergy Changing the Vision of the Church Work and Church Practices}

Finally, I shall analyze female clergy as agents of change in the daily work of the Church. How do clergywomen change the vision of Church work and the daily practices in the Church? This is done by analyzing male and female clergy and their perceptions of what is important in church work, what are the areas of church work which they see that are the key functions of the Church.

Both men and women regarded Church rites as the most important area of Church work. However, women reported that helping people and pastoral counseling are next important while men regarded proclaiming the word of God as the second most important task.

In general, clergywomen had a broader view of Church work and they regarded most areas of Church work as more important than clergymen. The only area of work that men regarded as statistically significantly more important than women is missionary work (see Table 1). Clergywomen put more emphasis on promoting equality, justice and the rights of the minorities than clergymen. Half 
of the clergywomen regarded promoting equality as very important in Church work compared to only one quarter of clergymen. Women also regarded helping people, supervising and mentoring, pastoral counseling, family work, education and musical activities as more important than men. This means that clergywomen put more emphasis than men on those tasks that can be regarded as "performance". At the same time there was no clear difference between men and women how much "the function" is emphasized. This means that clergywomen are trying to strongly apply religion and also use their position as members of the clergy in various social problems, problems of human dignity and inequality while many of the men think that the Church should concentrate mainly on "function", and less on "performance". Women's approach to work can be seen as a typically liberal approach to work while men have a more conservative view of Church work.

Table 1. Differences between male and female clergy in work orientation. Importance of various aspects of work on a scale 1 to $5(1=$ not important at all, $5=$ very important $)$. $\mathrm{N}=851$.

\begin{tabular}{|l|c|c|c|}
\hline & Male clergy & Female clergy & $\begin{array}{c}\text { Difference in means } \\
\text { (t-test) }\end{array}$ \\
\hline Promoting equality & 3.76 & 4.27 & $-8.10^{* * *}$ \\
\hline Promoting justice & 4.18 & 4.52 & $-6.44 * * *$ \\
\hline Promoting rights of the minorities & 3.55 & 3.95 & $-5.96 * * *$ \\
\hline Helping people in troubles & 4.61 & 4.79 & $-4.67 * * *$ \\
\hline Supervision and mentoring of trainees & 3.74 & 3.99 & $-4.15 * * *$ \\
\hline Helping people & 4.66 & 4.80 & $-3.66 * * *$ \\
\hline Societal influence & 3.57 & 3.80 & $-3.62 * * *$ \\
\hline Pastoral counseling & 4.67 & 4.80 & $-3.59 * * *$ \\
\hline Family work & 4.33 & 4.52 & $-3.33 * * *$ \\
\hline Prayer life & 4.45 & 4.61 & $-3.17 * *$ \\
\hline Musical activities & 4.04 & 4.19 & $-2.80 * *$ \\
\hline Education & 4.48 & 4.60 & $-2.62 * *$ \\
\hline Sunday service & 4.57 & 4.68 & $-2.16 *$ \\
\hline Church rites & 4.82 & 4.88 & -1.89 \\
\hline Reading and teaching the Bible & 4.38 & 4.45 & -1.24 \\
\hline Administrative work & 3.55 & 3.62 & -1.08 \\
\hline Confirmation work & 4.68 & 4.71 & -0.81 \\
\hline Proclaiming the word of God & 4.71 & 4.73 & -0.71 \\
\hline Evangelization & 3.67 & 3.60 & 0.92 \\
\hline Networking with the community & 3.88 & 3.83 & 0.95 \\
\hline Networking with civil sector, music and sports & 3.47 & 3.41 & 1.00 \\
\hline Missionary work & 4.25 & 4.12 & $2.04 *$ \\
\hline
\end{tabular}

$*$ = statistically significant at $5 \%$ level $(0.05) ; * *=$ statistically significant at $1 \%$ level $(0.01)$; $* * *=$ statistically significant at $0.1 \%$ level $(0.001)$

\section{Conclusions}

In this article I have analyzed clergywomen as potential change-makers in the Church. The context I analyzed is the Evangelical Lutheran Church of Finland. The article shows that the entrance of women 
into ordained ministry and increase in the number of female ministers have had and will have consequences in various areas of Church life.

Until now, women have typically been regarded as an undermined minority in the Church which has less impact on the actual Church life and practices than men. However, since the number of female ministers is increasing rapidly, the tendencies that are more apparent among women will have a greater emphasis in the Church in the future. The research results also indicate that women also have the courage to change the Church in practice. For example, the data show that those who have performed blessings of same-sex couples without the Church officially allowing them to have mainly been women.

In general, clergywomen are clearly changing the Church in a more liberal direction. They do it in various ways: they change the perception of faith and dogma, the policies of the church as well as daily practices in parishes. Female clergy are notably more open towards homosexual couples' rights in the Church and have also been more active in acting in favor of them. The data also show that attitudes towards same-sex couples have become more positive during the period 2002-2010, especially among female clergy. Among the men, they have remained more stable.

In general, the construction of faith among women is more individualized and not so dependent on traditional authorities than that of male clergy. Women are not so clearly attached to traditional dogma, they read the Bible less, but pray more than male clergy. Their attitude towards Church work is also more open to society. They consider it important that the Church is active in helping people and promoting equality, justice and rights of the minorities and not just proclaiming its message by talk.

Differences in work orientation among men and women also follow the socially constructed gender roles [27]: female clergy tend to emphasize "feminine tasks", such as pastoral counseling and helping others and not to concentrate so much on authoritative tasks. Clergywomen may do so, not only because they feel more attracted to such tasks, but also because they may feel that as a woman they are expected to do so. Women who are employed in a traditionally male-dominated field may also feel pressured to perform their "proper" gendered identities and to behave as they feel people expect them to behave as a woman. This is also a way of justifying women's ascent to these positions as spiritual authority, a position that has not been possible for a woman in most protestant churches until in the late 20th century (1988 in Finland), and is only a distant dream in Catholic and Orthodox churches.

Clergywomen put more emphasis on those tasks that can be regarded as "performance" while many of the men think that the Church should concentrate mainly on "function". Women's approach to work can be seen as typically liberal. This can also be seen as a way for the Church to maintain an active role in a broad field in society and even become more active. In this sense, the attitude towards Church work among clergywomen can also activate de-privatization on the Church [34].

As the majority church in Finland, the Evangelical Lutheran Church is in a difficult position in trying to adapt to the needs of its members. With $78 \%$ of Finns belonging into it, it is obvious that it cannot please everyone. In general, the study shows that clergymen are more likely to stick to traditional values and working cultures while women are more flexible and receptive to new ideas and towards making the Church more open to society. From this point of view it seems clear that the entrance of women into ministry has enabled the Church to keep better contact to those members who are more remote from it. At the same time more conservative members feel more remote and disappointed with the more liberal stands taken by the Church. 
The change brought into the Church can also be seen as an indicator of organizational secularization. Organizational secularization refers to "internal secularization" and religious change within religious institutions and can refer to any attempt to secularize or modernize the teachings of the Church in order to adapt to the secular values of society $[35,36]$. Some indicators of this process are a weaker attachment to traditional Church dogma, weaker role of the Bible and tolerant attitudes and common human values instead of dedication to the traditional religious teachings, values and practices. From the point of view of the results of this study it seems obvious that clergywomen are modernizing the Church in various ways in the level of teaching, policies and practices.

\section{References}

1. Chaves, M. Ordaining Women: The Diffusion of an Organizational Innovation. Am. J. Sociol. 1996, 101, 840-873.

2. Chang, P.M.Y. Female Clergy in the Contemporary Protestant Church: A Current Assessment. JSSR 1997, 36, 565-573.

3. Watling, T. 'Leadership' or 'Dialogue'? Women, Authority and Religious Change in a Netherlands Community. Sociol. Relig. 2002, 63, 515-538.

4. Lummis, A.T.; Nesbitt, P.D. Women Clergy Research and the Sociology of Religion. Sociol. Relig. 2000, 67, 443-453.

5. Nesbitt, P.D. Feminization of the Clergy in America: Occupational and Organizational Perspectives; Oxford University Press: New York, NY, USA, 1997.

6. Niemelä, K.; Salonen, K. Finnish attitudes toward female ministry in the beginning of the $21 \mathrm{st}$ Century. Tidskrift för kirke, Religion og Samfunn 2002, 2, 151-162.

7. Chaves. M.; Anderson, S. Continuity and Change in American Congregations: Introducing the Second Wave of the National Congregations Study. Sociol. Relig. 2008, 69, 415-440.

8. Kirkko numeroina/Työntekijät [Church Statistics/Personell. Statistics of the Evangelical Lutheran Church of Finland]. Church Council. Available online: http://evl.fi/EVLfi.nsf/Documents/ 9928383F1A4A4016C22572E5003B11B3?OpenDocument\&lang=FI (Accessed on 30 March 2010).

9. Niemelä, K. Papisto ja kanttorit 2010; Church Research Institute: Tampere, Finland, 2010.

10. Sullins, P. The Stained Glass Ceiling: Career Attainment for Women Clergy. Sociol. Relig. 2000, 61, 243-266.

11. Jackson, C.W.; Hargrove, B.; Lummis, A.T. Women of the Cloth: Now Opportunity for the Churches; Harper and Row: San Francisco, CA, USA, 1983.

12. Zikmund Brown, B.; Lummis, A.T.; Chang, P.M.Y. Clergy Women: An Uphill Calling; Westminster John Knox Press: Louisville, KY, USA, 1998.

13. Charlton, J. Women and Clergywomen. Sociol . Relig. 2000, 60, 419-424.

14. Charlton, J. Clergywomen of the pioneer generation: A longitudinal study. JSSR 1997, 36, 519-613.

15. Lehman, E.C., Jr. Gender and ministry style: Things not what they seem. In Gender and Religion; Swatos, W.H., Jr., Ed.; Transaction Publishers: London, UK, 1994; pp. 3-14. 
16. Lehman, E.C., Jr. Gender and Work: The Case of the Clergy; State University of New York Press: Albany, NY, USA, 1993.

17. Lummis, A. Why men and women leave the ministry: Hypotheses from research on clergy and from exiters of other statuses. In The Power of Gender in Religion; Weatherby, G.A., Farrell, S.A., Eds.; McGraw Hill: New York, NY, USA, 1996; pp. 119-138.

18. Niemelä, K. Calling or Vocation. Tidskrift for Kirke Religion Samfunn 1 2001, 43-52.

19. Niemelä K. Future theological professionals in Finland-A changing generation. In Education for Ministry in the Church of Sweden; Hansson, P., Ed.; Svenska kyrkans forskningråd: Uppsala, Sweden, 2001; pp. 109-126.

20. Niemelä, K. Teologiksi? Teologiseen tiedekuntaan pyrkivien uranvalintamotiivit ja ammatillinen suuntautuminen (Motives of Career Choice and Vocational Orientation of Applicants for Studies in Theology); Kirkon tutkimuskeskus: Tampere, Finland, 1999; Sarja A Nro 73.

21. Niemelä, K. 2010 Niemelä, Kati. Papisto ja kanttorit 2010. Akavan kirkollisten ammattiliittojen jäsenkyselyn raportti (The Clergy and Church Musicians 2010-Report of the Member Survey of Clergy Union and Union for the Church Musicians); Kirkon tutkimuskeskus: Tampere, Finland, 2010; www-julkaisuja Nro 20.

22. Niemelä, K. Doctrinal Views and Conflicts among Clergy and other Church Employees in Finland. Tidskrift for Kirke Religion Samfunn 1 2005, 47-71.

23. Niemelä, K. At the Intersection of Faith and Life: A narrative approach to the faith of church employees. Soc. Compass 2007, 54, 187-200.

24. Beyer, P. Religion and Globalization; Sage: London, UK, 1994.

25. Wuthnow, R. The Restructuring of American Religion. Society and Faith since World War II; Princeton University Press: Princeton, NJ, USA, 1998.

26. World Health Organization. What Do We Mean by "Sex" and "Gender"? In Gender, Women and Health; available online: http://www.who.int/gender/whatisgender/en/index.html (Accessed on 7 June 2010).

27. Eagly, A.H.; Wood, W.; Diekman, A.B. Social Role Theory of Sex Differences and Similarities: A Current Appraisal. In The Developmental Social Psychology of Gender; Eckes, T., Trautner, H., Eds.; Lawrence Erlbaum Associates, Inc.: Mahwah, NJ, USA, 2000; pp. 123-169.

28. Wood, W.; Eagly, A.H. A cross-cultural analysis of the behavior of women and men: Implications for the origin of sex differences. Psychol. Bull. 2002, 128, 699-727.

29. Gilbert, R.; Gilbert, P. Masculinity Goes to School; Routledge: London, UK, 1998.

30. Salonen, K. Pappisliiton jäsenkyselyn raportti 2002 (The report of the Clergy Union member survey 2002); Church Research Institute and Clergy Union Finland: Tampere, Finland, 2002.

31. Niemelä, K.; Palmu, H. Papisto ja kanttorit 2006. (Clergy and church musicians in 2006); Church Research Institute: Tampere, Finland, 2006.

32. Kääriäinen K.; Niemelä, K; Ketola, K. Religion in Finland. Decline, Change and Transformation of Finnish Religiosity; Church research institute: Tampere, Finland, 2005.

33. Sullins, D.P. Gender and Religion: Deconstructing Universtality, Constructing Complexity. Am. J. Sociol. 2006, 112, 838-880.

34. Casanova, J. Public Religion in the Modern World; University of Chicago: Chicago, IL, USA, 1994. 
35. Dobbelaere, K. Secularization: An Analysis at Three Levels. In Gods, Humans and Religion; P.I.E.-Peter Lang: Bruxelles, Belgium, 2002; No 1.

36. Luckmann, T. The Invisible Religion: The Problem of Religion in Modern Society; Macmillan: New York, NY, USA, 1967.

(C) 2011 by the authors; licensee MDPI, Basel, Switzerland. This article is an open access article distributed under the terms and conditions of the Creative Commons Attribution license (http://creativecommons.org/licenses/by/3.0/). 